\title{
Perubahan kekuatan impak resin akrilik polimerisasi panas dalam perendaman larutan cuka apel
}

\author{
*Suguh Bhaktiar Pribadi, **Moh.Yogiartono, **Titien Hary Agustantina \\ "Mahasiswa \\ ** Departemen Material Kedokteran Gigi \\ Fakultas Kedokteran Gigi Universitas Airlangga \\ Surabaya, Indonesia
}

\begin{abstract}
Acrylic resin being has been used in dentistry since 1946. Apple vinegar solution currently popular as healthy supplement drink. It consists of tanin (fenol), acid, and other subtances. Fenol and acid are able to chemically damage to acrylic resin. The purpose of this study was to investigate the impact strength of heat cured acrylic resin after immersed in apple vinegar solution. This experiment was carried out on the heat cured acrylic resin sample of size $65 \times 10 \times 2.5 \mathrm{~mm}$. The immersion periods varied from 45 minutes, 11 days, and 17 days. There were 42 samples, divided into 21 samples for three treatment groups and 21 samples for three control groups. The result showed that there were significant differences of acrylic resin strength after immersion in apple vinegar at 45 minutes and 17 days. The conclusion was the longer immersion time of acrylic resin in apple vinegar would reduce the impact strength.

Key words: acrylic resin, apple vinegar solution, impact strength
\end{abstract}

\begin{abstract}
ABSTRAK
Resin akrilik telah digunakan dalam bidang kedokteran gigi sejak tahun 1946, 98\% dari basis akrilik gigitiruan adalah polimer. Akhir-akhir ini cuka apel popular sebagai minuman kesehatan yang mengandung tanin (fenol) asam dan substansi lainnya. Fenol dan asam mampu merusak resin secara kimiawi. Tujuan penelitian ini adalah untuk mengetahui kekuatan impak dari resin akrilik polimerisasi panas setelah perendaman dalam larutan cuka apel. Penelitian dilakukan dengan menggunakan sampel akrilik polimerisasi panas dengan ukuran $65 \times 10 \times 2,5 \mathrm{~mm}$. Masa perendaman bervariasi dari 45 menit, 11 hari dan 17 hari. Empat puluh dua sampel dibagi dalam 21 sampel untuk 3 kelompok perlakuan dan 21 lainnya untuk 3 kelompok kontrol. Setiap kelompok terdiri dari 7 sampel. Hasilnya menunjukkan adanya perbedaan bermakna kekuatan impak resin akrilik setelah perendaman 45 menit dan 17 hari di larutan cuka apel. Dari penelitian ini dapat disimpulkan bahwa waktu perendaman resin akrilik yang lebih lama dalam larutan cuka apel mengurangi kekuatan impak resin akrilik.
\end{abstract}

Kata kunci: resin akrilik, larutan cuka apel, kekuatan impak

Korespondensi: Suguh Bhaktiar Pribadi, Moh.Yogiartono, Titien Hary Agustantina, Departemen Material Kedokteran Gigi, Fakultas Kedokteran Gigi Universitas Airlangga, Jln. Prof. Dr. Moestopo No.47 Surabaya 60132, Indonesia. Email: drg_yogiartono@yahoo.co.id

\section{PENDAHULUAN}

Resin akrilik digunakan di bidang kedokteran gigi mulai tahun 1946. Sebanyak 98\% dari semua basis gigitiruan dibuat dari polimer atau kopolimer metil metakrilat. ${ }^{1}$ Polimer (metil metakrilat) murni tidak berwarna, transparan, dan padat. Pada 
penggunaan di bidang kedokteran gigi, polimer diberi warna agar faktor estetika terpenuhi sesuai dengan warna rongga mulut yang normal. ${ }^{2}$ Resin akrilik merupakan suatu polimer yang mempunyai peran penting dalam pembuatan gigitiruan lepasan, reparasi gigitiruan, dan prostesis maksilofasial untuk menggantikan struktur rongga mulut atau sebagian wajah yang hilang. ${ }^{3}$

Jenis resin akrilik yang sering dipakai adalah polimerisasi panas karena memiliki beberapa keunggulan, yaitu memenuhi syarat estetik, stabilitas warna baik, tidak mengiritasi, tidak toksik, harga relatif murah, cara pengerjaannya mudah, pembuatan dan reparasi mudah. Resin akrilik mempunyai beberapa kekurangan, yaitu dapat menyerap air atau cairan, sisa makanan atau bahan kimia, serta mudah patah bila terjatuh pada permukaan yang keras. ${ }^{4}$

Untuk memastikan ketidaklarutan dan kestabilan dimensi basis gigitiruan sebuah bahan cross-linked dapat ditambahkan pada monomer. Bahan crosslinked ini dapat menyebabkan resin akrilik menjadi lebih keras, tahan terhadap pemanasan, tahan terhadap goresan, dan tahan terhadap cairan pelarut. Untuk hal ini dapat digunakan glycol dimethacrylate $1-2 \%$ atau alkyl dimethacrylate. $^{2}$

Cuka apel merupakan minuman kesehatan hasil dari proses fermentasi alami buah apel. Penyajian buah apel dalam bentuk cuka adalah optimalisasi manfaat zat yang terkandung dalam buah apel. Proses fermentasi alaminya membuat kandungan nutrisi cuka apel semakin besar, terutama kandungan enzim dan asam amino (Brosur pabrik). Cuka apel yang dibuat dari sari buah apel bertambah populer sebagai minuman kesehatan karena, antara lain sebagai pencegah asam urat, penyakit jantung dan paru, dan sejumlah penyakit lain (Brosur Pabrik). Salah satu zat aktif yang terdapat dalam buah apel adalah tanin yang berwarna coklat muda. Tanin merupakan senyawa polifenol. Fenol bila berkontak dengan resin akrilik dapat menyebabkan kerusakan kimiawi pada permukaan resin akrilik. $^{5}$ Perusakan secara kimia menimbulkan kekasaran pada permukaan resin akrilik sehingga dapat menyebabkan retak atau crazing dan penurunan kekuatan serta kekerasan. ${ }^{2}$ Senyawa fenol dapat berdifusi ke dalam lempeng akrilik dan mulai menyebabkan perusakan kimiawi resin akrilik. $^{5}$

Larutan asam dari larutan cuka apel bila bereaksi dengan resin akrilik akan menyebabkan perubahan kimia, yaitu terjadi kelarutan beberapa bahan pengisi. Kelarutan ini akan menyebabkan banyaknya ruang-ruang kosong di antara matrik polimer sehingga memudahkan terjadinya ikatan antara unsur-unsur yang ada pada cairan dengan matrik polimer di tempat tersebut, yang akan mempengaruhi sifat mekanis dari resin akrilik terutama kekuatan impak. ${ }^{6}$

Pada pemakai gigitiruan yang mengkonsumsi cuka apel sebagai minuman kesehatan, setiap kali minum diperkirakan larutan cuka apel akan kontak dan tinggal di dalam rongga mulut selama 15 menit. ${ }^{7}$ Jika seseorang minum 3 kali maka dalam 1 hari terjadi paparan cuka apel selama 45 menit pada gigi dan rongga mulut. Perendaman resin akrilik selama 45 menit sama dengan orang mengkonsumsi larutan cuka apel selama 1 hari, perendaman 11 hari sama dengan mengkonsumsi larutan cuka apel selama 1 tahun, dan perendaman 17 hari sama dengan mengkonsumsi larutan cuka apel selama 1,5 tahun. Aturan pemakaian larutan cuka apel yang ideal adalah 2 sendok makan cuka apel $(30 \mathrm{ml})$ dicampur dengan air $150 \mathrm{ml}$ dan diminum 3 kali dalam sehari. Perendaman resin akrilik dalam akuades selama 45 menit, 11 hari, dan 17 hari, juga menunjukkan adanya perbedaan yang bermakna. ${ }^{8}$ Hal ini disebabkan sifat porositas 
dari resin akrilik yang mudah menyerap cairan yang didukung oleh pernyataan Anusavice ${ }^{2}$ bahwa resin akrilik akan mengalami kejenuhan bila direndam dalam air selama 17 hari.

Larutan cuka apel merupakan minuman kesehatan. Kandungan fenol dalam larutan cuka apel kemungkinan dapat mempengaruhi sifat resin akrilik, terutama sifat mekanik. Sifat mekanis resin akrilik antara lain kekuatan impak. Kekuatan impak yang optimal diperlukan untuk mencegah kemungkinan terjadi kepatahan/fraktur pada basis gigitiruan yang terbuat dari resin akrilik. Kepatahan/fraktur tersebut dapat terjadi sewaktu dilakukan pembersihan gigitiruan secara rutin sehari-hari, misalnya gigitiruan resin akrilik terjatuh membentur lantai yang keras. Berdasar pemikiran tersebut di atas maka perlu dilakukan suatu penelitian mengenai perubahan kekuatan impak resin akrilik polimerisasi panas jenis crosslinked setelah perendaman dalam larutan cuka apel.

Artikel ini melaporkan hasil penelitian mengenai perubahan kekuatan impak resin akrilik polimerisasi panas dalam perendaman larutan cuka apel.

\section{BAHAN DAN METODE}

Jenis penelitian ini adalah eksperimental laboratorik dengan menggunakan post-test only control group design. Jumlah sampel minimal yang diperlukan untuk setiap kelompok sampel adalah 7, jumlah sampel seluruhnya adalah 42 . Kriteria sampel antara lain bentuk dan ukuran $65 \mathrm{x}$ $10 \times 2,5 \mathrm{~mm},{ }^{9}$ permukaan halus dan tidak porus.

Sampel dibagi menjadi 5 kelompok, yaitu Kelompok I adalah resin akrilik polimerisasi panas jenis cross-linked direndam dalam akuades selama 45 menit, Kelompok II adalah resin akrilik polimerisasi panas jenis cross-linked direndam dalam akuades selama 11 hari, Kelompok III adalah resin akrilik polimerisasi panas jenis crosslinked direndam dalam akuades selama 17 hari, Kelompok IV adalah resin akrilik polimerisasi panas jenis cross-linked direndam dalam larutan cuka apel selama 45 menit, Kelompok V adalah resin akrilik polimerisasi panas jenis cross-linked direndam dalam larutan cuka apel selama 11 hari, dan Kelompok VI adalah resin akrilik polimerisasi panas jenis cross-linked direndam dalam larutan cuka apel selama 17 hari. Variabel bebas pada peneitian ini adalah perendaman resin akrilik polimerisasi panas tipe cross-linked dalam larutan cuka apel selama 45 menit, 11 hari, dan 17 hari.

Variabel terikat pada penelitian ini adalah kekuatan impak resin akrilik polimerisasi panas jenis cross-linked. Variabel terkendali adalah resin akrilik polimerisasi panas jenis cross-linked, ukuran lempeng uji 65 x 10 × 2,5 mm. ${ }^{9}$ Kekuatan impak resin akrilik diukur dengan Impact Testing Machine (Tokyo Testing Machine, MFG. Co. Ltd/Torsee's memakai metode Charpy).

Bahan yang digunakan pada penelitian ini adalah resin akrilik polimerisasi panas jenis crosslinked merk "Stellon", gips keras dan gip lunak, vaselin, bahan separasi, cuka apel merk "Tahesta" dan akuades. Alat yang digunakan pada penelitian ini adalah model master logam dengan ukuran 65 x $10 \times 2,5 \mathrm{~mm},{ }^{2}$ kuvet besar, vibrator, bowl dan spatula gips, pisau malam, kertas selofan, pres hidrolik, pot porselen untuk mengaduk akrilik, panci larutan cuka apel, termometer, kasa steril, pengaduk, kompor, botol kaca gelap, gelas ukur, kertas gosok no. 1, timbangan analitis, Impact Testing Machine (Tokyo testing Machine, Meg. CO. Ltd/Torsee's).

\section{Prosedur penelitian}

Gips lunak dengan perbandingan air dan bubuk $100 \mathrm{gr}$ : $50 \mathrm{ml}$ (sesuai aturan pabrik) diaduk di atas vibrator selama 0,5 menit, lalu dimasukkan 
ke dalam kuvet besar yang disiapkan di atas vibrator. Pengisian gips lunak ke dalam kuvet bawah hanya setengah tinggi kuvet ditunggu sampai gips lunak mengeras. Gips keras diaduk dengan perbandingan bubuk dan air $100 \mathrm{~g}: 30 \mathrm{ml}$ (sesuai aturan pabrik) di atas vibrator selama 0,5 menit dan dimasukkan ke dalam kuvet bawah yang telah terisi gips lunak di atas vibrator. Model master diulas vaselin diletakkan di atas permukaan gips keras pada kuvet bawah dengan posisi mendatar sampai setengah tebal model master masuk tertanam dalam gips keras, kemudian ditunggu sampai mengeras. Kemudian, permukaan atas gips keras dan model master diulas vaselin. Selanjutnya kuvet lawan dipasang dan dituang adonan gips keras sambil diletakkan di atas vibrator sampai memenuhi setengah kuvet atas, ditunggu sampai mengeras. Kemudian gips lunak dituangkan ke dalam kuvet dan dipres, ditunggu sampai mengeras. Setelah mengeras kuvet dibuka dan model master diambil, dituangi air mendidih untuk membersihkan sisa vaselin, sehingga diperoleh cetakan (mould) sampel yang bersih. Cetakan diulasi could mould seal dengan kuas dan tunggu sampai kering.

Bubuk dan cairan resin akrilik dengan perbandingan $23 \mathrm{mg}: 10 \mathrm{ml}$ (sesuai petunjuk pabrik), diaduk sampai homogen di dalam pot porselin, kemudian pot ditutup. Setelah mencapai tahap dough, adonan akrilik dimasukkan ke dalam cetakan sampel dan dilapisi plastik, kemudian kuvet atas ditutup dan ditekan dengan pres hidrolik perlahan-lahan dengan tekanan 3 atm. Selanjutnya kuvet dibuka, kelebihan akrilik dipotong dan kuvet ditutup. Kemudian ditekan dengan pres hidrolik kembali. Penekanan kuvet diulang sampai tidak ada kelebihan akrilik, lalu dipindahkan ke dalam hand press. Cetakan yang sudah terisi dengan resin akrilik polimerisasi panas digodok dalam air, kemudian air dipanaskan sampai $100{ }^{\circ} \mathrm{C}$ selama 20 menit (sesuai petunjuk pabrik), kemudian dibiarkan sampai dingin (suhu ruang). Setelah dingin hasil akrilik diambil, kelebihan akrilik digosok dan dihaluskan dengan kertas gosok no.1 (halus) di bawah air mengalir selama 10 menit.

\section{Pembuatan larutan cuka apel}

Cuka apel dalam botol dikocok dahulu agar endapan dapat tercampur. Cuka apel diambil sebanyak $30 \mathrm{ml}$ dan dimasukkan dalam botol berisi akuades steril $150 \mathrm{ml}$, kemudian diaduk 10 kali (aturan pakai dari pabrik).

Perendaman sampel, sampel dibagi menjadi 6 kelompok dengan masing-masing terdiri dari 7 sampel. Sebelum dilakukan pengujian, lempeng akrilik direndam dalam akuades steril dengan suhu kamar $\left(30{ }^{\circ} \mathrm{C} \pm 1{ }^{\circ} \mathrm{C}\right)$ selama 48 jam. ${ }^{9}$ Kelompok pertama, kedua, dan ketiga masing-masing direndam dalam akuades selama 45 menit, 11 hari, 17 hari. Kelompok keempat, kelima, dan keenam masing-masing direndam dalam larutan cuka apel selama 45 menit, 11 hari, 17 hari. Larutan perendam diganti setiap hari (24 jam).

$$
\text { Rumus Kekuatan impak }=\frac{\mathrm{W} \times \mathrm{L}(\cos \beta-\cos \alpha)}{\mathrm{A}}\left(\mathrm{cmkg} / \mathrm{cm}^{2}\right)
$$

A

Keterangan : $\mathrm{W}=$ berat bandul + berat logam $(\mathrm{kg})$

$\mathrm{L}=$ panjang lengan $(\mathrm{cm})$

$\alpha=$ sudut awal bandul sebelum diayunkan

$\beta=$ sudut akhir bandul sesudah diayunkan

$\mathrm{A}=$ luas penampang dari lempeng uji $\left(\mathrm{cm}^{2}\right)$ 
Diantara pergantian larutan perendaman lempeng akrilik, dilakukan pembilasan dengan akuades. ${ }^{10}$

Pengujian lempeng uji terhadap kekuatan impak resin akrilik menggunakan impact testing instrument dengan serangkaian tahap berikut ini. Lempeng uji resin akrilik diletakkan horisontal dan keduanya difiksasi menggunakan plastisin pada tempat sampel. Bandul dengan berat tertentu dan dengan lengan panjang tertentu diletakkan pada ketinggian tertentu sehingga membentuk sudut $90^{\circ}(\alpha)$. Jarum penunjuk skala diatur pada posisi nol. Bandul dilepas sehingga memukul lempeng uji resin akrilik tepat di bagian tengah. Setelah bandul kontak dengan lempeng uji, bandul masih berayun sebesar sudut $\beta$. Besar sudut $\beta$ dicatat. $^{12,13}$

Hasil yang diperoleh dimasukkan ke dalam rumus kekuatan impak.

Penelitian dilakukan di Departemen Material Kedokteran Gigi Fakultas Kedokteran Gigi Universitas Airlangga Surabaya dan Laboratorium Metalurgi Fakultas Teknik Industri Jurusan Teknik Mesin Institut Teknologi Sepuluh Nopember Surabaya.

\section{HASIL PENELITIAN}

Data yang diperoleh dari uji kekuatan impak resin akrilik polimerisasi panas jenis cross-linked pada perendaman dalam akuades dan larutan cuka apel dengan tiga waktu perendaman yang berbeda, kemudian dicari rerata dan simpang baku atau standar deviasi yang dapat dilihat dalam tabel 1.

Pada tabel 1 dapat diketahui bahwa makin lama waktu perendaman resin akrilik maka nilai kekuatan impak makin menurun.

Sebelum dilakukan uji statistik parametrik menggunakan Anova satu arah, perlu dilakukan pengujian normalitas data pada masing-masing kelompok perlakuan dengan menggunakan uji Kolmogorov Smirnov. Suatu data dikatakan berdistribusi normal jika signifikansi lebih besar dari 0,05 dan jika signifikansi lebih kecil atau sama dengan 0,05 maka data tidak berdistribusi normal.

Hasil uji normalitas data pada masing-masing kelompok perlakuan menunjukkan nilai signifikansi lebih besar dari 0,05 yang berarti data berdistribusi normal. Selain itu juga dilakukan uji homogenitas varian menggunakan uji Levene's. Hasil uji homogenitas menunjukkan nilai signifikansi lebih besar dari 0,05 yang berarti seluruh data dalam penelitian ini homogen. Setelah itu, dilanjutkan dengan uji Anova satu arah untuk mengetahui beda kemaknaan yang ada di antara nilai rerata kekuatan impak kelompok perlakuan yang dapat dilihat pada tabel 2 .

Tabel 1. Nilai rerata dan standar deviasi dari kekuatan impak resin akrilik jenis polimerisasi panas pada enam macam perlakuan perendaman $\left(\mathrm{kg} / \mathrm{cm}^{2}\right)$

\begin{tabular}{cccc}
\hline kelompok & N & rerata & SD \\
\hline I & 7 & 0,524 & 0,080 \\
II & 7 & 0,495 & 0,052 \\
III & 7 & 0,400 & 0,038 \\
IV & 7 & 0,533 & 0,066 \\
V & 7 & 0,429 & 0,052 \\
VI & 7 & 0,391 & 0,025 \\
\hline
\end{tabular}

Keterangan: $\mathrm{SD}=$ standar deviasi 
Tabel 2. Hasil uji Anova satu arah dari penelitian mengenai kekuatan impak resin akrilik jenis polimerisasi panas pada enam macam perlakuan perendaman $\left(\mathrm{kg} / \mathrm{cm}^{2}\right)$

\begin{tabular}{cccccc}
\hline & Sum of squares & $d f$ & Mean square & $F$ & Sig \\
\hline Between groups & 0,139 & 5 & 0,028 & 9,020 & 0,000 \\
Within groups & 0,111 & 36 & 0,003 & & \\
Total & 0,251 & 41 & & & \\
\hline
\end{tabular}

Tabel 3. Hasil uji LSD dari penelitian mengenai kekuatan impak resin akrilik jenis polimerisasi panas pada enam macam perlakuan perendaman $\left(\mathrm{kg} / \mathrm{cm}^{2}\right)$

\begin{tabular}{lcccccc}
\hline Kelompok & $\begin{array}{c}\text { Kelompok } \\
\text { I }\end{array}$ & $\begin{array}{c}\text { Kelompok } \\
\text { II }\end{array}$ & $\begin{array}{c}\text { Kelompok } \\
\text { III }\end{array}$ & $\begin{array}{c}\text { Kelompok } \\
\text { IV }\end{array}$ & $\begin{array}{c}\text { Kelompok } \\
\text { V }\end{array}$ & $\begin{array}{c}\text { Kelompok } \\
\text { VI }\end{array}$ \\
\hline Kelompok I & - & 0,344 & $0,000^{*}$ & 0,758 & $0,003^{*}$ & $0,000^{*}$ \\
Kelompok II & 0,344 & - & $0,003^{*}$ & 0,212 & $0,032^{*}$ & $0,001^{*}$ \\
Kelompok III & $0,000^{*}$ & $0,003^{*}$ & - & $0,000^{*}$ & 0,344 & 0,754 \\
Kelompok IV & 0,758 & 0,212 & $0,000^{*}$ & - & $0,001^{*}$ & $0,000^{*}$ \\
Kelompok V & $0,003^{*}$ & $0,032^{*}$ & 0,344 & $0,001^{*}$ & - & 0,210 \\
Kelompok VI & $0,000^{*}$ & $0,001^{*}$ & 0,754 & $0,000^{*}$ & 0,210 & - \\
\hline
\end{tabular}

Keterangan:

* = ada beda bermakna

Kelompok I : perendaman dengan akuades selama 45 menit.

Kelompok II : perendaman dengan akuades selama 11 hari.

Kelompok III : perendaman dengan akuades selama 17 hari.

Kelompok IV : perendaman dengan larutan cuka apel selama 45 menit.

Kelompok V : perendaman dengan larutan cuka apel selama 11 hari.

Kelompok VI : perendaman dengan larutan cuka apel selama 17 hari.

Hasil uji Anova satu arah diperoleh tingkat signifikansi 0,000 . Tingkat signifikansi ini kurang dari 0,05 maka terdapat beda bermakna antar kelompok perlakuan. Hasil uji tersebut menunjukkan lama perendaman resin akrilik polimerisasi panas dalam larutan cuka apel mempengaruhi kekuatan impak. Dari hasil uji ini terlihat bahwa makin lama waktu perendaman resin akrilik maka nilai kekuatan impak makin menurun.

Untuk mengetahui lebih lanjut perbedaan yang ada antar kelompok perlakuan maka dilakukan uji lanjut menggunakan Least Significant Difference (LSD). Hasil uji LSD dapat dilihat pada tabel 3 .
Hasil uji LSD menunjukkan sebagian besar kelompok perlakuan memiliki beda bermakna, kecuali pada Kelompok I dengan Kelompok II dan Kelompok IV, Kelompok II dengan Kelompok I dan Kelompok IV, Kelompok III dengan Kelompok V dan Kelompok VI, Kelompok IV dengan Kelompok I dan Kelompok V, Kelompok V dengan Kelompok III dan Kelompok VI, dan Kelompok VI dengan Kelompok V dan Kelompok III.

\section{PEMBAHASAN}

Penelitian ini dilakukan untuk mengetahui apakah ada perubahan kekuatan impak pada lempeng resin akrilik polimerisasi panas jenis 
cross-linked setelah perendaman dalam larutan cuka apel dalam berbagai waktu yang berbeda.

Hasil penelitian yang terlihat pada tabel 1 menunjukkan nilai kekuatan impak perendaman resin akrilik polimerisasi panas dalam akuades selama 17 hari lebih rendah dibandingkan dengan perendaman dalam akuades selama 11 hari dan perendaman 45 menit. Berdasarkan analisis statistik penurunan tersebut pada tabel 3 menunjukkan ada beda bermakna antara kelompok sampel resin akrilik polimerisasi panas yang direndam dalam akuades selama 17 hari dengan 11 hari dan 45 menit.

Penurunan kekuatan impak disebabkan proses kejenuhan oleh karena penyerapan air oleh resin akrilik polimerisasi panas. ${ }^{2}$ Penyerapan air terjadi secara difusi. Proses difusi merupakan migrasi atau berpindahnya suatu substansi melalui rongga. Molekul air dapat menembus kepadatan polymethil methacrylate atau resin akrilik dan menempati posisi di antara rantai polimer yang mengakibatkan rantai polimer terdesak dan memisah. Dari mekanisme ini maka penyerapan air oleh resin akrilik polimerisasi panas dapat mempengaruhi sifat mekanis termasuk kekuatan impak. ${ }^{2}$ Hal ini terlihat dalam penelitian ini bahwa makin lama resin akrilik polimerisasi panas direndam dalam akuades makin rendah nilai kekuatan impak.

Nilai kekuatan impak resin akrilik polimerisasi panas yang direndam dalam larutan cuka apel selama 17 hari lebih rendah dibandingkan dengan nilai kekuatan impak hasil perendaman dalam larutan cuka apel selama 11 hari dan 45 menit. Berdasarkan analisis statistik menunjukkan ada beda bermakna antara kelompok sampel resin akrilik polimerisasi panas yang direndam dalam larutan cuka apel selama 17 hari dengan yang direndam selama 45 menit. Hal ini mungkin disebabkan oleh kandungan senyawa fenol dalam larutan cuka apel yang memperbesar nilai penurunan kekuatan impak.

Menurut Shen, ${ }^{5}$ fenol dengan konsentrasi 5\% apabila kontak dengan resin akrilik menunjukkan peningkatan berat oleh karena penyerapan air dan pengaruh kimia pada morfologi permukaan resin akrilik. Senyawa fenol dapat diserap oleh permukaan resin akrilik dan menyebabkan permukaan resin akrilik menjadi mengembang dan lunak. Resin akrilik mempunyai sifat menyerap air atau cairan. Fenol merupakan suatu senyawa yang terkandung dalam larutan cuka apel dan mempunyai berat molekul yang lebih kecil dari berat molekul polimer resin akrilik. Hal ini menyebabkan fenol dapat berpenetrasi ke dalam lempeng resin akrilik dan terjadi pemutusan rantai panjang polimer resin akrilik. Sebagai akibatnya, ikatan antar molekul menurun sehingga menurunkan kekuatan resin akrilik termasuk kekuatan impak. Kemungkinan lain adanya larutan asam dari larutan cuka apel bila bereaksi dengan resin akrilik akan menyebabkan perubahan kimia, yaitu yang terjadi adalah kelarutan beberapa bahan pengisi. Selama mengalami reaksi saat berpolimerasi, ikatan karbon ganda silang bereaksi dengan oligomer, membentuk ikatan dengan bahan pengisi menjadi matrik polimer. Ikatan ini dapat terdegradasi oleh absorbsi air dari resin akrilik selama digunakan. Adanya kelebihan ion $\mathrm{H}^{+}$pada kelarutan asam akan menyebabkan ketidakstabilan ikatan kimia dari resin akrilik. Ion $\mathrm{H}^{+}$dari asam menyebabkan degradasi ikatan polimer sehingga beberapa monomer dari resin akrilik melepaskan diri, yang disertai pelepasan bahan pengisi yang ada. Adanya kelarutan ini akan menyebabkan banyaknya ruang-ruang kosong di antara matrik polimer sehingga memudahkan terjadinya ikatan antara unsur-unsur yang ada pada cairan dengan matrik polimer di tempat tersebut. ${ }^{6}$ 
Nilai kekuatan impak resin akrilik polimerisasi panas yang direndam dalam larutan cuka apel selama 17 hari lebih rendah dibanding selama 11 hari tetapi secara statistik tidak terdapat beda bermakna. Hal ini mungkin disebabkan selisih penurunan kekuatan impak yang sedikit di antara kedua kelompok sampel. Selisih penurunan kekuatan impak di antara kedua kelompok sampel tersebut berada dalam rentang nilai kekuatan impak yang sama, sehingga secara statistik tidak ada beda bermakna.

Nilai kekuatan impak resin akrilik polimerisasi panas yang direndam dalam akuades selama 17 hari secara statistik tidak ada beda bermakna dibanding yang direndam dalam larutan cuka apel selama 11 hari. Hal ini dapat diartikan bahwa kekuatan impak resin akrilik yang direndam dalam larutan cuka apel selama 11 hari setara dengan kekuatan impak resin akrilik yang direndam dalam akuades selama 17 hari. Hal tersebut mungkin disebabkan adanya kandungan senyawa fenol dalam larutan cuka apel yang mempunyai peran lebih besar dalam menurunkan kekuatan impak dibanding akuades.

\section{SIMPULAN}

Berdasarkan hasil penelitian tentang perubahan kekuatan impak resin akrilik polimerisasi panas dalam perendaman larutan cuka apel dapat disimpulkan bahwa makin lama perendaman resin akrilik polimerisasi panas dalam larutan cuka apel makin menurunkan kekuatan impaknya.

\section{SARAN}

Berdasarkan hasil penelitian di atas, disarankan perlu penelitian lebih lanjut tentang pengaruh larutan cuka apel terhadap sifat-sifat resin akrilik lainnya.

\section{DAFTAR PUSTAKA}

1. Craig RG, Powers JM. Restorative dental materials. $9^{\text {th }}$ ed. St. Louis: CV Mosby Company; 2002. p. 431-50.

2. Anusavice KJ. Phillips: Buku ajar ilmu kedokteran gigi. Jakarta: Penerbit Buku Kedokteran EGC; 2003. hal. 197-218.

3. Hatrick CD, Eakle WS, Bird WF. Dental materials. Philadelphia: Saunders; 2003. p. 251-4.

4. Combe EC. Notes on dental material. $6^{\text {th }}$ ed. Edinburgh: Churchill Livingstone; 1992. p. 123-5.

5. Shen C, Nikzad SJ, Frank AC. The effect of glutaraldehyde base desinfectans on denture base resins. J Prosthet Dent 1974; 61: 583-9.

6. Billmeyer FW. Textbook of Polimer Sciences. $3^{\text {rd }}$ edition, New York: Jhon Willy and Sons; 1994. p: 11-16.

7. Kusdarjanti E. Kekuatan transversa resin akrilik jenis heat cured yang direndam dalam minuman tuak. Maj Ked Gigi 2003; 36: 160-3.

8. Linda YA. Kekuatan transversa resin akrilik heat cured setelah direndam dalam larutan cuka apel. [Skripsi]. Surabaya: Fakultas Kedokteran Gigi Universitas Airlangga; 2006. hal. 1-3.

9. American Dental Association (ADA). A guide to dental material and devices. $7^{\text {th }}$ ed. Chicago: American Dental Association; 1974. p. 70-106.

10. Widyaningrum D. Perubahan kekuatan impak resin akrilik heat cured tipe cross-linked dalam perendaman infusa daun saga $10 \%$. [Skripsi] Surabaya: Fakultas Kedokteran Gigi Universitas Airlangga; 2004. Hal. 1-2.

11. Debby. Therapi madu dan cuka apel. Available from www.mal_archieve.com/ balita-anda@indoglobal.com/msg23156.html. Accessed on March 5, 2005.

12. Anderson JN. Applied dental material. $5^{\text {th }}$ ed. Oxford: Blackwell Scientific Publication; 1977. p. 245-66.

13. Mc Cabe JF. Applied dental materials $7^{\text {th }}$ ed. Oxford: Blackwell Scientific Publication; 1990. p. 87-96. 